\title{
Spontaneous discharge from Gartner's duct cyst in a perimenopausal woman: a rare case
}

\author{
Sathiyakala Rajendran*
}

\begin{abstract}
Department of Obstetrics \& Gynaecology, Sri Sathya Sai Medical College and Research Institute, Thiruporur, Tamil
\end{abstract} Nadu, India

Received: 20 January 2015

Accepted: 16 February 2015

\section{*Correspondence:}

Dr. Sathiyakala Rajendran,

E-mail: sathya_jipmer@yahoo.co.in

Copyright: (C) the author(s), publisher and licensee Medip Academy. This is an open-access article distributed under the terms of the Creative Commons Attribution Non-Commercial License, which permits unrestricted non-commercial use, distribution, and reproduction in any medium, provided the original work is properly cited.

\begin{abstract}
Gartner's duct cyst which arises from the remnants of the distal part of Wolffian duct is rare, especially in a perimenopausal woman. Hereby, presenting a case of huge Gartner's duct cyst with spontaneous discharge in a perimenopausal woman. A 40 year old woman, who is having mass descending per vaginum for the past 2 years and discharge from the mass for the past one week, is diagnosed to have a Gartner's duct cyst in the right lateral vaginal wall. There was mucous discharge from the cyst through a pin hole opening in the vaginal wall covering the cyst. Under antibiotic cover, the cyst was excised completely. The patient was advised follow up.
\end{abstract}

Keywords: Gartner's duct cyst, Wolffian duct, Mucous secreting cyst in vagina

\section{INTRODUCTION}

Gartner's duct cyst which arises from the remnants of caudal part of Wolffian duct is very rare, especially in perimenopausal age group. In this case report, huge Gartner's duct cyst in a perimenopausal woman with spontaneous discharge from the cyst is reported. Most of the cysts are less than $2 \mathrm{~cm}$ and remain asymptomatic for a long time. As these are closed spaces, they may enlarge due to collection of mucus secretion. Spontaneous ruptures of these cysts or malignant transformation in these cysts are extremely rare.

\section{CASE REPORT}

A 40 year old perimenopausal woman came to the gynecological outpatient department with complains of mass descending per vaginum for the past two years and discharge from the mass for the past one week. She noticed the mass two years back which is constant and not increasing in size. The discharge from the mass was sudden in onset, spontaneous, moderate in amount, mucoid in consistency, pale white in colour and not associated with pain, fever or itching in genitalia. There was no dysuria, urinary retention, urinary incontinence, injury, abdominal or pelvic pain and abnormal vaginal bleeding. Her physical examination revealed a cystic swelling of size $8 \times 7 \mathrm{~cm}$ in the right lateral vaginal wall, just inside the introitus. The swelling was non tender, fluctuant, cystic with well-defined margins. Mucoid discharge was noticed from a pin hole opening in the vaginal mucosa covering the cyst. Rest of the examination findings and laboratory investigations were normal. Ultrasound failed to detect any genitourinary abnormalities. Under antibiotic cover, complete excision of the cyst and repair of vaginal wall was done without any complications. Patient was advised follow up.

\section{DISCUSSION}

Most cysts found in vagina are embryological remnants of either Mullerian ducts or Wolffian ducts. 
Embryologically, the genital and urinary systems are intimately associated. They originate from mesoderm. During the eighth week of embryonic development, the paired Mullerian ducts meet and fuse to form the uterus and vagina whereas in the male fetus they disappear.

Wolffian ducts form the epididymis, vas deferens, ejaculatory duct, seminal vesicles, ureters and collecting tubules. In the female fetus, the Wolffian ducts run towards the body of the uterus and disappear by the third month. Occasionally, the remnants of the distal parts of the ducts persist. Mullerian and Wolffian duct derivatives can be present in almost any part of the vaginal wall. Clinically, the distinction between the Mullerian and Gartner's duct cyst is of little importance. ${ }^{1}$

Gartner's duct cyst arises from the vestigial remnant of Wolffian duct. Most common location is anterolateral vaginal wall, ${ }^{2}$ above the level of the inferior most aspect of the pubic symphysis. ${ }^{3}$ These cysts are small, average diameter being $2 \mathrm{~cm}$ and remain asymptomatic for a long time. More commonly these cysts are detected as an incidental finding on routine gynecological examination. Sometimes, these cysts may enlarge with mucinous secretion and become symptomatic. The largest cyst reported measured $16 \times 15 \times 8 \mathrm{~cm}^{4}$

Huge cysts will interfere with sexual intercourse, vaginal delivery or cause vaginal discomfort. Infection, spontaneous rupture or malignant transformations of these cysts are extremely rare. Gartner's duct cyst are sometimes associated with urinary tract abnormalities such as ectopic ureters or ipsilateral renal hypoplasia. ${ }^{5}$ Ectopic ureters, besides having direct communications with the vagina and introitus, have been reported to communicate with Gartner's duct cyst and cause urinary incontinence. $^{2}$

Differential diagnosis include: mullerian duct cysts, Skene's gland cyst, urethral diverticulum, epidermal inclusion cyst, cystocele, and Bartholin's cysts. Skene's ducts are located in the lamina propria of the lower third of the female urethra and opens on the lateral aspect of the external urethral meatus. Cysts of Skene's gland are caused by obstruction of the ducts. Skene's gland cyst is typically located at the posterolateral aspect of the external urethral meatus.

Urethral diverticulum is a localized out pouching of the urethra into the anterior vaginal wall. The presenting symptoms include dysuria, post micturition dribbling and dyspareunia. MRI and virtual computed tomography urethroscopy confirms the diagnosis.

Epidermal inclusion cysts after episiotomy or surgical closure of a vaginal flap are usually found in vaginal wall. Epidermal clitoral inclusion cyst is one of the long term complications of female circumcision, which is common in Africa and among few immigrant communities in North America and Europe. These inclusion cysts are filled with keratin and desquamated epithelial cells.

Cystocele and anterior vaginal wall cyst can be easily differentiated clinically and radiographically. Clinically, the size of the cystocele decreases after emptying the bladder. Radiographically, the cyst can be differentiated from cystocele by filling the bladder with contrast.

Bartholin's duct cysts are located medial to the labia minora in the posterolateral wall of vagina at or below the level of pubic symphysis. This location helps to differentiate them from the Gartner's duct cyst, which occurs superiorly in the vagina. MRI is the imaging modality of choice in tracing the origin of the cysts and confirming the diagnosis. ${ }^{4}$

Treatment of Gartner's duct cyst include marsupialisation or excision of cyst or aspiration and tetracycline sclerotherapy. ${ }^{6}$

\section{Funding: No funding sources \\ Conflict of interest: None declared \\ Ethical approval: Not required}

\section{REFERENCES}

1. Eilber KS, Raz S. Benign cystic lesions of the vagina: a literature review. J Urol. 2003;170(3):71722.

2. Kier R. Non ovarian gynecologic cysts: MR imaging findings. AJR Am J Roentgenol. 1992;158(6):12659.

3. Israel GM, Lee VS, Resnick D, Lavelle MT, Krinsky GA, Nitti V, et al. Magnetic resonance evaluation of the urethra, lower genitourinary tract in symptomatic women. J Women's Imaging. 2002;4:165-72.

4. Hagspiel KD. Giant Gartner duct cyst: magnetic resonance imaging findings. Abdom Imaging. 1995;20(6):566-8.

5. Dwyer PL, Rosamilia A. Congenital urogenital anomalies that are associated with the persistence of Gartner's duct: a review. Am J Obstet Gynecol. 2006 Aug;195(2):354-9.

6. Abd-Rabbo MS, Atta MA. Aspiration and tetracycline sclerotherapy: a novel method for management of vaginal and vulvar Gartner cysts. Int J Gynaecol Obstet. 1991 Jul;35(3):235-7.

DOI: $10.5455 / 2320-1770 . i j r \operatorname{cog} 20150445$

Cite this article as: Rajendran S. Spontaneous discharge from Gartner's duct cyst in a perimenopausal woman: a rare case. Int J Reprod Contracept Obstet Gynecol

2015;4:497-8. 